\title{
Editorial Themed Issue: Relationships With Others
}

\author{
Robyn Zink
}

Welcome to this themed issue of the Australian Journal of Outdoor Education. All of the articles in this issue examine the question of relationships with others. The scope and the breadth of articles is indicative of the complexity of how relationships with others work, why developing positive relationships with others is important and how outdoor education can contribute to this.

Dewey (1938) argued that learning occurs through interaction. Learning, in this sense, is not something that happens in isolation, it is something that happens in relation to the individual who has the experience, the others involved, and the environment in which it occurs. According to the way Dewey conceptualises learning the relationships learners have with others is fundamental to the process of learning. This runs counter to the way learning, particularly experiential learning, is construed as an individual experience by many contemporary authors. For example Beard and Wilson (2006), point out that learning is personal and the filtering of experience is an individual process. The picture of learning that Beard and Wilson draw here appears to have little to do with interaction. If learning is such a personal and individual process, interaction may in fact "get in the way" of learning. Fenwick (2001) suggests that a major conception of experiential education presumes "an independent learner, cognitively reflecting on concrete experience to construct new understandings, perhaps with the assistance of an educator, toward some social goal of progress or improvement" (p. 7). Here learning is still seen as an individual process, but Fenwick suggests there may be a place for interactions with a teacher or instructor to assist with that learning.

The shift from learning occurring through interaction to learning being a personal and individual experience has occurred in a broader context where neo-liberal political and economic ideologies have come to the fore in many Western countries. The rise of neo-liberalism has seen the promotion of the logic of the market-place in all aspects of our lives. This works on the assumption that individuals make rational choices based on their best interest and that this is "more 'efficient' at directing the social distribution of goods and services than the political institution of the state" (Hales, 2006, p. 55). Numerous writers within the field of outdoor education have made links between neo-liberal ideologies and contemporary outdoor education practices. In 1998 Chris Loynes wrote about adventure in a bun. He was commenting on how adventure has come to be seen as a commodity like any other commodity in a capitalist society. He argued that capitalist markets have stripped outdoor education of its transformative potential and it is like any other commodity that can be packaged and replicated in a standardised fashion. Connection and relationships are lost in this process of the commodification of outdoor education.

Like Loynes, Jay Roberts (2012) also utilises the work of Ritzer (1993; 2001) in drawing parallels between contemporary practices of experiential education and the processes of McDonalisation that are replicated in so many aspects of our lives. The dimensions of McDonalisations that he particularly focuses on are efficiency, calculability, predictability, and control. Roberts illustrates how these dimensions shape contemporary outdoor education practices, particularly in relation to ropes courses. He argues that in this neo-liberal complex "the individual is not located socially, transformatively, or critically... but rather consumptively as a decontextualized and depoliticised individual consumer" (Roberts, 2012, p. 95, original emphasis). Learning in this environment is not only an individual process, but the individual who learns is disconnected from the social world and the environment in which they are located.

Robert Hales (2006) extended this argument by suggesting that outdoor educators have to think carefully about how they respond to the rise of individualism. Just putting young people together in a group is not enough to counter this as the subjectivity that emerges through the neo-liberal complex is that of the autonomous individual who meets their needs through the rubric of free choice. Hales warns that young people may not see the relevance of the group or of community, let alone of the environment, and therefore, may be resistant to pedagogical strategies that endeavour to bring the group to the fore.

This themed issue of the Australian Journal of Outdoor Education explores relationships with others. Do relationships with others still matter, and if so is outdoor education a space where relationships with others can develop? Given Hales (2006) contention that young people may de-value relationships with others, how do young people who participate in outdoor education experiences conceptualise relationships with other participants and, if they do value them, how are relationships with others important? 
The articles in this issue of AJOE certainly suggest that relationships with others are important for both teachers and for students in outdoor education contexts. Genny Blades and Lucus Bester open this issue by exploring a pedagogy of attunement, which they suggest is a relation-responsive pedagogy. They use the work of Martin Buber, particularly his philosophy of dialogue expressed as the "I-It" and "I-Thou" principles. They explore this in relation to the disconnected world in which we live and are seeking a more connected "self" that teaches. Buber's work provides Blades and Bester with a way of opening up their senses and opening up to relations with others.

Whereas Blades' and Bester's work is a philosophical exploration of relationship, Jeremy Jostad, Jim Sibthorp and Karen Paisley offer a methodological approach to mapping relationships that form during an extended outdoor education experience. They use Social Network Analysis to map relationships which give insight into how different group members interact with each other. The main aim of the paper is to explain Social Network Analysis as it is a methodological tool that has received little attention in the outdoor education field. They highlight the contribution that this tool can make to understanding how relationships form and work in groups with an example from the National Outdoor Leadership School (NOLS) and groups of different compositions of students receiving scholarships.

Murray Henstock, Katrina Barker and Jorge Knijnik examined the role that relationships play in re-engaging disengaged youth in further education. Five people who participated in an extended voyage on the sail training ship STS Young Endeavour were interviewed. One of the themes to emerge from the data is the role social networks play in making the participants feel more positive toward further education. This enabled participants to feel more confident about contributing and also gave them a greater sense of belonging. Participants clearly identified activities such as climbing aloft, watch interactions, group debriefs and taking command of the ship as contributing to their sense of belonging and connection with the other crew members.

Graham Scott, Margaret Boyd and Derek Colquhoun shift the focus on the relationships between teachers and pupils and between pupils in outdoor experiences. They worked with a group of teachers who had little experience teaching in outdoor environments. The teachers were nervous about losing control over their students and about losing their expert status as teachers. Scott, et al., report that teachers generally found their students more engaged and better behaved in the outdoors and that not being an expert in the subject matter opened possibilities for quite different relationships with students. The blurring of roles between expert and student contributed to shared positive learning experiences for both teachers and students. Students also reported communicating with one another more effectively than they do in class settings.

In the final article in this issue, Tony Robinson reports on the relationships that emerged through participation in a Year 9 experiential education programme. Like Scott, et al., Robinson explores how teacher/student and student/student relationships shift and change through the programme. He found that for the students the most significant parts of the programme were those that allow for relationships to develop with their teachers outside of the classroom.

All of these articles point to the importance of relationships that emerge and develop with others through outdoor education experiences. They highlight the link between positive relationships and learning. The work of the likes of Loynes, Roberts and Hales does paint a rather bleak picture of education that is formulaic and focused on the autonomous individual to the determinant of community and connection, but the articles in this issue complicate that picture. There is no denying the pressure on outdoor education programmes to deliver pre-determined outcomes in increasingly shorter time frames with an attendant privileging of learning as an individual process. The work in this issue suggests that teaching and learning does occur through interaction and when those interactions are positive, both teaching and learning can be enhanced.

There are also two book reviews in this issue. John Quay reviews Outdoor adventure and social theory. This book is edited by Elizabeth Pike and Simon Beames and the series of chapters explores how the work of different social theorists and different social theories can contribute to our understanding of Adventure Education. Peter Martin reviews Outdoor education in Aotearoa New Zealand: A new vision for the twenty first Century. This book is edited by David Irwin, Jo Straker and Allen Hill. The various contributors examine what outdoor learning could or should look like in the changing world we live in.

Finally two Ph.D theses are profiled in this issue of the journal. 
Once again I would like to thank all of the people that have contributed to making this issue possible. I would like to particularly welcome those authors who have not published in AJOE before. It is heartening to see so many new authors in this issue.

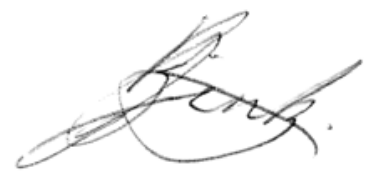

Robyn Zink

Editor

\section{References:}

Beard, C. \& Wilson, J.P. (2006). Experiential learning. A best practice handbook for educators and trainers ( $2^{\text {nd }}$ ed.). London: Kogan Page.

Dewey, J. (1938). Experience and education. New York: Collier Macmillan.

Fenwick, T.J. (2001). Experiential learning: A theoretical critique from five perspectives. Columbus, $\mathrm{OH}$ : Centre on Education and Training for Employment.

Hales, R. (2006). The rise of individualism. The implications for promoting relations between self, others and the environment in outdoor education. Australian Journal of Outdoor Education, 10(2), 53-61.

Loynes, C. (1998). Adventure in a bun. The Journal of Experiential Education, 21(1), 35-39

Roberts, J. W. (2012). Beyond learning by doing: Theoretical currents in experiential education. New York: Routledge. 